\title{
AN IMPORTANT CONTRIBUTION TO THE DISCUSSION ON RESEARCH METHODS AND TECHNIQUES IN DESIGNING
}

\author{
Oleg KAPLIŃSKI \\ Faculty of Architecture, Poznań University of Technology, Nieszawska 13C, Poznań, 60-965, Poland
}

Submitted 05 October 2015; accepted 19 October 2015

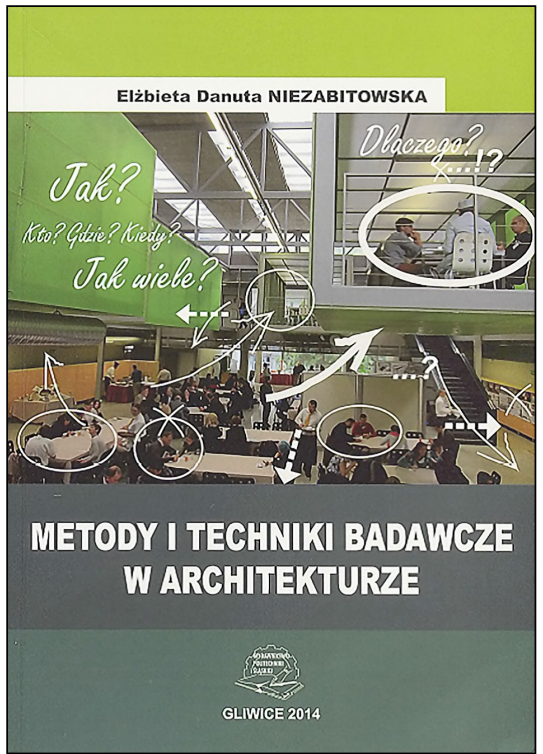

Technological progress, the rate of information flow, and possibilities of verifying knowledge constitute a foundation for falsifying knowledge. The knowledge which has been classified (which has been put through a verification test) creates the basis of science. We live in the times, when the borders of knowledge expand rapidly. The degree of advancement in some disciplines vary, thus the presence of attempts to question some of them as scientific disciplines. It is particularly true about engineering design, construction technology and the discipline in architecture related to civil engineering, see W. Bonenberg 2009, S. Brand 1994 and R. Foque $(1996,2010)$. There is a claim that ar- chitecture - the basic discipline affiliated to designing has not solidified yet, because there is still a problem with a uniform definition of a paradigm. A scientific paradigm is a collection of notions and theories, constituting a basis for a given discipline of science. All the same, what is important is the architect's knowledge and its interpretation.

A new book, written by Professor Elżbieta Niezabitowska, Research Methods and Techniques in Architecture (Niezabitowska 2014), is very helpful in solving such dilemmas, highlighting the subject of falsification of knowledge. The book is extensive - there are 437 pages in nine chapters and one appendix.

The author's thesis is that architecture is still in the phase of creating paradigms. The author supports this claim with some of her colleagues' observations, for example researchers from the University of Arts and Design in Helsinki (UIAH). The author understands a need to create a paradigm of an interdisciplinary science in architecture. Architecture is a multidimensional phenomenon, in other words, it is inter-, multi- and trans-disciplinary.

Therefore, the book under review is devoted not only to different study methods and techniques, but also to issues on the peripheries of science and design. It is good that the author differentiates between types of studies in architecture, both substantial and procedural. The former are strictly scientific, carried out in existing structures, with the intention of enriching knowledge about rules and principles of functioning of 
the environment, in other words, they are aimed at diagnosing and at building theories. They describe relationships between environment and people functioning within this environment. They can be categorised as ex post studies. Procedural studies focus on perfecting design processes, and are connected with the designer's workshop. They can be categorised as ex aute studies. An interesting reference to mention here are texts written by J. Lang 1987 and A. Niezabitowski 2009.

Architectural research seeks answers to questions regarding the (surrounding and designed) reality. We can find examples of such questions in chapter 4 . The author notes, in particular, the so-called triangulation of studies. In architectural research, triangulation methods are used more and more often, and it is the result of weakness of some research materials and apply and research techniques. It is especially visible in quality testing. The point is in multifaceted research techniques used, and the number of times when they are used to verify and corroborate the results.

And extensive, 46 page chapter is devoted to research methods themselves. It is difficult to separate methods from techniques, nevertheless the author makes an attempt to classify research methods in 10 groups. It may be interesting to quote the whole range of those methods and add a few comments.

Group 1: logical argumentation methods, including analysis, synthesis, induction, analogies, and so forth, using falsification of knowledge;

Group 2: historical interpretation methods. Typological studies constitute an important element of historical research which has major practical significance in design processes.

Group 3: experimental research. The author writes that, in this case, studying passive and zero energetic microclimate conditions in experimental buildings is a new, very broad research field in architecture, equally new is testing their impact on health and well being of users in residential and office buildings. Obviously, the author has noted simulation studies, including 3-D modelling.

Group 4: statistical and quantitive methods. Unfortunately, not enough intention was devoted to regression and correlation methods;

Group 5: modelling and simulation studies (including the iconic ones) which are quite common. The following books can be suggested to the reader: e.g. Kapliński (1997, 2007);
Group 6: quality test methods. This group of methods in architecture has been methodologically well developed as POE (Post-Occupancy Evolution). Two remarks here. First, at the Department of Architecture at the Silesian University of Technology, where the author works, POE is a separate subject of lectures and classes. Second, the extension of this method, namely BPE (Building Performance Evaluation) is not discussed enough in the book - see the work by Sh. Mallory-Hill et al. (2012) and the recent publication by J. Palmer and P. Armitage (2014);

Group 7: case studies;

Group 8: action research methods as intervention methods - quite commonly used by architects in the USA;

Group 9: heuristic and forecasting methods. Most often, heuristic methods work as support in design processes;

Group 10: mixed methods (discussed in different parts of the book).

Al listed methods greatly facilitate falsification of knowledge in architecture. The methods utilise techniques discussed in chapter 7. It is an ambitious and extensive chapter. The techniques have been categorised in 23 subject sets. Quite a few of those techniques have been illustrated with author's own examples or examples originating from the Silesian University of Technology research teams. Unfortunately, in most cases, the examples do not instruct how to use the techniques.

The author also writes about the life cycle of a building. In chapter 8 , she presents research techniques used in different phases of life cycle of buildings, which will certainly be interesting for architects.

What is crucial is that the author is quite realistic (and critical) about research techniques and methods in architecture, and even about her own environment. I would like to highlight a few aspects of the above.

Firstly, the author underlines the fact that using study methods which have a weak potential of verification opens the door to unlimited freedom of interpretation. This, and following remarks of the author underlines the situation of architecture which, at least in Poland, is still in the pre-paradigmatic phase.

Secondly, the author regards history of architecture bound with the history of art to be, academically, most advanced sub-discipline of architecture. She appreciates the strong aspects of that sub-discipline, 
nevertheless also underlines its weaknesses. The major weakness is narrowing architectural issues primarily to artistic aspects, ignoring such very important aspects as the technical and usage, and social and cultural issues. The more so that methods used to study artistic objects are insufficient in studying such complex functions as space and architectural structures.

Thirdly, it is clear from the context of the book that the lack of certification, mentioned above, the lack of knowledge and usage of study techniques and methods in architecture is reflected in the level of promotional works (dissertations). And this obviously influences the development of knowledge in a given branch. On page 101 we find a sad conclusion: "In Poland, research work in architecture is not appreciated, especially in the so-called built environment (...), because in the view of the majority of professionals, research should focus on eminent works; while others think that theoretical papers are immature and have little practical sense".

This is why I am of the opinion that this book may fill a certain void in the awareness, and may make the public understand the need of development of architecture as a discipline.

Supposedly the author hopes that help in creating a need to build a paradigm of an interdisciplinary science into formal qualifications of future professionals can be found in the Europian 85/384/EEC Directive (see Council 1985).

Fourthly, the author emphasizes that currently three important areas of dynamic research, i.e., Universal Design, Design out Crime (Design for Safe), and sustainable development are the most promising and fastest growing areas of development in architecture. Unfortunately, as the author confirms, all three are developed by cognate sciences, almost entirely without participation of the architects, to the detriment of the quality of architecture and built environment, which hinders cooperation in interdisciplinary research teams.

The book touches upon a few subjects which have not been discussed above. In its current version is quite extensive (437 pages) but is also well grounded in the references, counting as many as 335 titles. It is good that the author only points at developing generative and parametric design methods. At the moment, those design methods are regarded to be an area of professional skills, connected with computer techniques. I suggest that, in the second edition of the book, the au- thor should urgently widen the sphere of knowledge within the framework of universal design, inclusive design, and functional/usage value management. Doubtless, architects lack this knowledge. An absolute drawback of this book absence of mention about integrated design. In the countries of our geographic circle this terminology (and methods) has not been yet adopted, while the American Institute of Architects has already developed the next version, i.e., Integrated Project Delivery, a sought for method of organising and researching investment process (see AIA 2007). In the second edition, I suggest to include the subjects of broadly understood (though controversial) optimisation in architecture, not only within the framework of LCCA (LifeCycle Cost Analysis) but also within the framework of MCDA (Multiple-Criteria Decision Analysis) - see e.g. A. Kaklauskas and E. Zavadskas (2015), E. Zavadskas (2000) and E. Zavadskas et al. (1994).

Nonetheless, the book reads like a long, pleasant essay on science, scientific paradigms and their position, including falsification of knowledge in architecture. The reader may not agree with some of the classification of methods and techniques suggested by the author but an architect, and especially an academic teacher (required present a promotional dissertation) should know their position within the systems presented in the book. The book will be very useful at the departments of architecture. It should be obligatory reading at MA and doctoral courses in architecture.

Life itself has written an epilogue. The book has become a basis for cyclical conferences on "Interdisciplinary Researches in Architecture". The first conference took place in Gliwice on 23-24 April 2015.

\section{References}

The American Institute of Architects (AIA). 2007. Integrated project delivery: a guide. 2007 version 1, IAI National / California Council. 57 p.

Bonenberg, W. 2009. On architecture, education and research in architecture, Czasopismo Techniczne 1(A1): 18-23.

Brand, S. 1994. How buildings learn. What happens after they're built. Viking Penguin.

Council Directive 85/384/EEC of 10 June 1985 on the mutual recognition of diplomas, certificates and other evidence of formal qualifications in architecture, including measures to facilitate the effective exercise of the right of establishment and freedom to provide services. Official Journal L 223, 21/08/1985, Brussels, 0015 - 0025 .

Foque, R. 2010. Building knowledge in architecture. Antwerp: University Press Antwerp. 
Foque, R. K. V. 1996. Design research: the third way, in T. J. M. Van der Voordt, H. Hoogdalem, H. B. Van Vegen (Eds.). Doctorates in design and architecture. Vol. 1. Delft: Delft University Press, 125-129.

Kaklauskas, A.; Zavadskas, E. K. (Eds.) 2015. Multiple criteria analysis of the life cycle of the built environment. Vilnius: Technika. 448 p.

Kapliński, O. 1997. Modelling of construction processes: A managerial approach. Warszawa: Polska Akademia Nauk, Instytut Podstawowych Problemów Techniki. 175 p.

Kapliński, O. (Ed.) 2007. Metody i modele badań w inżynierii przedsięwzięć budowlanych [Methods and models of research in engineering construction projects]. Warszawa: Instytut Podstawowych Problemów Techniki (in Polish).

Lang, J. 1987. Creating architectural theory: the role of the behavioral sciences in environmental design. New York: Van Nostrand Reinhold.
Mallory-Hill, Sh.; Preiser, W. F. E.; Watson, Ch. G. 2012. Enhancing building performance. Wiley-Blackwell. $360 \mathrm{p}$.

Niezabitowska, E. D. 2014. Metody i techniki badawcze $w$ architekturze [Research methods and techniques in architecture]. Gliwice: Silesian University of Technology Press. 335 p. (in Polish).

Niezabitowski, A. M. 2009. Architectonics - a system of exploring architectural forms in spatial categories, International Journal of Architectural Research 3(2): 92-129.

Palmer, J.; Armitage, P. 2014. Building performance evaluation programme. early findings from non-domestic projects. London: Innovate UK. 47 p.

Zavadskas, E. K. 2000. Mehrkriterielle Entscheidungen im Bauwesen. Vilnius: Technika. 208 p.

Zavadskas, E. K.; Peldschus, F.; Kaklauskas, A. 1994. Multiple criteria evaluation of projects in construction. Vilnius: Technika. 226 p.

Oleg KAPLIŃSKI. Professor of Civil Engineering at Faculty of Architecture, Poznań University of Technology, Poland. The author of 240 publications. Doctor Honoris Causa of VGTU (1996). His research interests include: an integral management, integral design and risk management. 